\title{
At-Turats
}

Jurnal Pemikiran Pendidikan Islam

journal homepage: http://jurnaliainpontianak.or.id/index.php/atturats

\section{BUDAYA LITERASI DAN PEMANFAATAN SOSIAL MEDIA PADA MASYARAKAT AKADEMIK}

\author{
Muhamad Tisna Nugraha
}

Fakultas Tarbiyah dan Ilmu Keguruan (FTIK)

Institut Agama Islam Negeri (IAIN) Pontianak

Email: tisnanugraha2014@yahoo.com

\begin{abstract}
A B S T R A K
Incresingly and rapidly technology progress encouraging on more improving user amount of internet base services. Various features on internet base services creating people start to change from conventional media forms books, megazines and newspapers into online base media. Not only as consumer, some becomes part of spreading information especially in social network. Then,from this services people can share thoughts, opinions, knowledges, ideas or communications sharing only without knowing time and place. Although on the other side social media existence not always have positive impact, some part of it individually or group using this services as way to do various criminal acts, other has pragmatic characters and apathetic with social media as long as not bothering personal interests. Based on this,the writing will peeling more about how utilization social media on community especially on academician community aspects.
\end{abstract}

Key words: literation, social media and academician community.

\section{PENDAHULUAN}

Sosial media saat ini telah menjadi tempat bagi jutaan umat manusia untuk berkumpul. Berbagai produk yang ditawarkan seperti blogspot, wordpress, facebook, twitter, instagram, youtube dan berbagai layanan berbasis jejaring sosial (social network) telah menjadi lahan subur bagi penggunanya untuk berinteraksi dengan banyak orang di berbagai belahan dunia. Melalui layanan-lanyanan sosial media itu pula para pengguna dapat berbagi informasi bermanfaat seputar aktivitas yang sedang dikerjakan, ide, gagasan, opini dan tulisan ilmiahnya.

Dari sekian banyak jejaring sosial media yang ada di dunia maya, facebook dan twitter merupakan layanan sosial media yang paling banyak digunakan oleh netizen (pengguna sosial media). Hal ini sebagaimana data yang dikemukakan oleh Nufransa Wira Sakti (2014: 19-20), bahwa Jumlah pengguna twitter diseluruh dunia di tahun 2011 telah mencapai angka 383 juta orang. Pengguna layanan ini yang berasal dari Indonesia menempati urutan ke lima dengan jumlah pengguna sebanyak 19.5 juta orang. Tiga peringkat besar selanjutnya diduduki oleh Amerika Serikat, Brazil dan Jepang dengan jumlah angka pengguna berturut-turut yaitu 107 juta, 33 juta dan 29 juta orang. Untuk jejaring sosial berupa facebook, jumlah penggunanya berada pada angka fantastis yaitu sudah di atas 500 juta orang.

Dari data statistik Socialbakers.com Indonesia berada pada peringkat ketiga dengan jumlah pengguna sebanyak 43.39 
juta. ${ }^{1}$ Sebelumnya di tahun 2013 jumlah sebagaimana telah disebutkan di atas telah menggalami perubahan, sebagaimana disampaikan oleh Wakil Presiden ASEAN Blogger Community Indonesian Chapter, Administrator ASEAN Community, dan ketua Fan Page Facebook ASEAN Community (dalam Buletin ASEAN, 2013: 52) bahwa dari data pengguna internet di dunia, Indonesia tercatat sebagai pengguna terbesar ke-5 facebook (lebih dari 47 juta orang) dan ke-4 untuk twitter (sekitar 20 juta orang). ${ }^{2}$

Latar belakang yang menjadikan layanan facebook dan twitter sebagai sosial media terfavorit bukanlah tanpa alasan. Banyaknya fitur yang ditawarkan dengan berbagai kelebihan dari aplikasi ini yang kemudian menjadi faktor utama netizen lebih memilih menggunakan facebook dibandingkan dengan layanan sosial media lainnya. Lebih lanjut dilihat dari subtansi, jika, facebook lebih menonjolkan bagi diri atau personal seseorang sehingga hal ini menjadi lebih mudah 'terendus' segi narsisismenya, maka twitter justru menampung eksistensi seseorang dengan cara yang lebih sedikit elegan.

Sebagai contoh apabila kita mengetik kata kunci misalnya Michael Jackson, bisa saja kata ini sedang banyak dicari dan menjadi trending topics yang membuat pengguna akun twitter lainnya penasaran dan ingin tahu 'ada apa dengan Michael Jackson'. Dari hal tersebut itu pula tidak berlebihan jika portal berita televisi internasional dan lokal seperti CNN, BBC, Kompas, Trans TV dan lainnya juga memiliki akun facebook dan twitter.

Penggunaan jejaring sosial media ini juga menjadi sebuah fenomena yang terbilang cukup dahsyat atau bombastis. Dampaknya tidak hanya berada di kalangan bawah, namun juga turut dirasakan oleh masyarakat akademik yang dianggap

\footnotetext{
${ }^{1}$ Nufransa Wira Sakti, Buku Pintar Pajak ECommerce: Dari Mendaftar Sampai Bayar, (Ciganjur: Visi Media. 2014), hlm. 19-20.
}

sebagai bagian dari masyarakat pemegang tradisi intelektual dan keilmuan di Perguruan Tinggi. Pada aspek tertentu layanan berbasis internet juga digunakan sebagian bagian dari sebuah tatananan kehidupan kampus, terutama dalam rangka penyebaran informasi terkait perkembangan ilmu pengetahuan dan teknologi termasuk publikasi hasil penelitian dalam bentuk jurnal online. Hal ini sebagai bagian dari upaya untuk melakukan regristrasi (pendaftaran/ pengenalan), rekognisi (pencatatatan/ identifikasi) dan sertifikasi (labelisasi kualitas) terhadap karya-karya yang telah disusun oleh insan cendikiawan di Perguruan Tinggi.

Budaya akademik (academic culture) yang dicirikan dengan tradisi ilmiah berupa budaya literasi tak pelak juga turut berperan dalam mendorong optimalisasi sosial media seperti facebook dan twitter sebagai suatu bentuk kemitraan dialogis. Publikasi ilmiah, interaksi online dalam bentuk grup diskusi, serta sharing komunikasi seputar tulisan/kajian ilmiah dan lain-lain, sehingga hal tersebut menjadikan peran sosial media menjadi bagian dari suatu kemanfaatan untuk hal-hal positif. Tetapi teknologi bermanfaat seperti semacam ini juga bagaikan pisau bermata dua. Selain mendatangkan banyak hal-hal positif, ada pula yang justru memanfaatkannya demi kepentingan sesaat bahkan cenderung ke arah kriminal. Berangkat dari paradigm tersebut, tulisan ini akan membahas bagimana budaya literasi dan pemanfaatan sosial media pada masyarakat akademik.

\section{BUDAYA LITERASI DAN SOSIAL MEDIA}

Kata budaya berasal dari akar kata budh $\rightarrow$ budhi $\rightarrow$ budhaya, yang dalam bahasa Sansekerta dapat diartikan sebagai akal, sehingga arti dari kebudayaan

2 Buletin ASEAN, Media Publikasi Direktorat Jenderal Kerjasama ASEAN, (Jakarta: Kementerian Luar Negeri RI. Edisi 3 Nopember 2013), hlm. 52. 
mengacu pada hasil pemikiran atau akal manusia. ${ }^{3}$ Dari definisi tersebut kata budaya menunjuk pada hasil cipta, karsa dan rasa manusia dalam sejarah. Selanjutnya A. Rani Usman (2009: 59) menjelaskan bahwa budaya dapat diartikan sebagai suatu cara hidup yang berkembang dan dimiliki bersama oleh sebuah kelompok dan diwariskan oleh satu generasi ke generasi lainnya. ${ }^{4}$ Atau dengan kata lain budaya adalah suatu hasil kreatifitas yang berasal dari masyarakat di masa lalu dan diwariskan secara turun temurun ke generasi selanjutnya, sehingga bentuk dari suatu kebudayaan bisa saja berasal dari berbagai elemen kehidupan yang rumit serta diwariskan dari suatu generasi ke generasi lain melalui tradisi lisan dan tulisan dalam bentuk manisfestasi kehidupan berupa sistem sosial, politik, adat istiadat, pakaian, rumah (tempat tinggal), dan produk karya seni.

Adapun kata literasi diambil dari istilah literacy, Inggris yang diartikan sebagai kemampuan membaca dan menulis. Pada masyarakat modern membaca dan menulis sudah menjadi salah satu bentuk kecakapan hidup (life style) sekaligus bagian paling mendasar dari sekian banyak kegiatan yang dilakukan manusia di dalam kehidupannya. Bagi manusia modern, tanpa membaca dan menulis mereka akan ketinggalan informa-si penting dalam kehidupaunnya. Mereka akan termarginalkan serta hilang ditelan perubahan zaman. Inilah salah satu alasan kenapa Elizabeth Tjahjadarmawan (2017), menyatakan bahwa "Siapa menguasai informasi, dialah yang mnguasai dunia". 5

Budaya literasi sebenarnya mulai mengalami peningkatatan dalam hal eksistensinya ketika individu berada pada lingkungan pendidikan/sekolah. Meskipun

${ }^{3}$ Sarinah, Ilmu Sosial Budaya Dasar: Di Perguruan Tinggi, (Yogyakarta: Deepublish. 2016), hlm. 11.

${ }^{4}$ A. Ranu Usman. Etnis Cina Perantau di Aceh, (Jakarta: Yayasan Pustaka Obor Indonesia. 2009), hlm. 59. demikian, faktanya budaya literasi dalam suatu negara tidak hanya dipengaruhi oleh motivasi seseorang melainkan juga turut dipengaruhi oleh unsur-unsur tradisi dan budaya yang ada dalam masyarakat sekitaranya. Tidak mengherankan jika semakin tinggi minat baca dalam suatu masyarakat, maka semakin tinggi pula indikator budaya literasi yang dimilikinya.

Adapun yang dimaksud dengan masyarakat akademik dapat diartikan sebagai suatu tatanan kehidupan yang berada di lingkungan kampus atau di lingkungan perguruan tinggi yang menjadi pusat usaha pemahaman, pengembangan dan peningkatan kualitas ilmu pengetahuan. Rhenald Kasali (2008: xiv) menyatakan bahwa dunia akademik merupakan sumber ilmu pengetahuan, sumber-sumber nilai dan pusat referensi. Selain itu, ciri dari dunia akademis melekat pada universali-tasnya, obyektivitasnya dan tidak berpihak pada interest orang perorang atau kelompok dan cenderung mengedepankan hajat hidup orang banyak. ${ }^{6}$

Ada banyak referensi mengenai kehidupan masyarakat akademik di Indonesia. Salah satunya yang ditulis oleh Afrisal Mutahir (dalam Riris K. Toha Sarumpaet, 2016: 52) dengan menggunakan paradigma dari teori arena Bourdieu atas kiprah intelektual masyarakat akademik Indonesia bagi kemaslahatan bangsanya. Dia mendeskripsikan perbandingan data jumlah doktor yang meningkat drastis di abad XXI dengan produk ilmiahnya. Menurutnya informasi telah membawa berkah berupa peningkatan drastis jumlah sarjana, magister dan doktor. Di tahun 2006 misalnya, jumlah professor di Indonesia sudah mencapai angka 5.000 orang. Padahal pada tahun 2001 jumlahnya belum

\footnotetext{
5 Elizabeth Tjahjadarmawan. Ngopi Dulu, (Yogyakarta: Deepublish. 2017), hlm. 1.

${ }^{6}$ Rhenald Kasali, Mutasi DNA Powerhouse, (Jakarta: PT. Gramedia Pustaka Utama. 2008), hlm. xiv.
} 
mencapai 1.000 orang. ${ }^{7}$ Peningkatan jumlah ini belum lagi ditambah dengan jumlah riset, perestasi dan produk hasil penelitian yang berhasil dikembangkan.

Selanjutnya yang dimaksud dengan sosial media menurut Ridwan Sanjaya (2010: 65) adalah suatu media berbasis jaringan internet yang memungkinkan para penggunanya untuk dapat berinteraksi secara langsung dengan pengguna lainnya di dunia maya. Sosial media juga dianggap sebagai wadah berekspresi sekaligus wahana untuk mengembangkan kepribadian. Melalui sosial media seseorang bisa belajar sopan santun, adab berkomunikasi, bertukar pikiran, berdiskusi, mencurahkan kegelisahan dan lain-lain. Hal ini didukung dari adanya fitur berupa fasilitas obrolan (chating), pengiriman pesan ke banyak teman, menulis testimonial di dinding teman, dan sebagainya. Tentu saja dengan adanya interaksi global tersebut, masyarakat akan mengetahui kebiasaan orang lain dan berbagi banyak informasi meskipun mereka berada di belahan dunia yang lain. ${ }^{8}$

Keberadaan media sebagai sarana penyampaian informasi telah menjadi kekuatan bagi manusia dalam rangka mengemban tugasnya selaku khalifah di muka Bumi. Kekuatan ini sudah di isyaratkan Allah SWT berfirman dalam AlQur'an Surah Ar-Rahmaan (55): 33: ${ }^{9}$

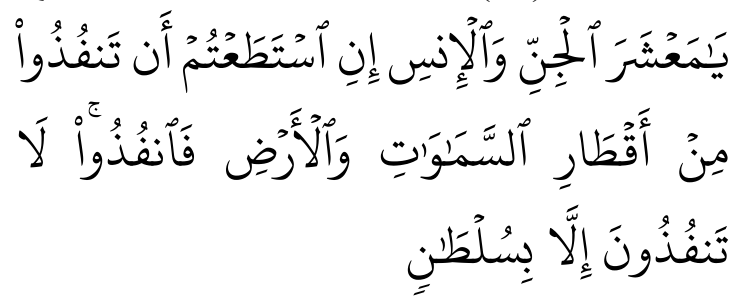

${ }^{7}$ Riris K. Toha Sarumpaet, Krisis Budaya?: Oasis Guru Besar Fakultas Ilmu Pengetahuan Budaya UI, (Jakarta: Yayasan Pustaka Obor Indonesia. 2016), hlm. 51.

8 Ridwan Sanjaya, Christine Wibhowo, Arista Prastyo Adi, Parenting Untuk Pornografi di Internet, (Jakarta: PT. Gramedia. 2010), hlm. 65.

${ }^{9}$ Dalam. Buku Muhammad Nasib Ar-Rifa'I, ayat tersebut bahwa jin dan manusia tidak akan sanggup melarikan diri dari keputusan dan ketetapan Allah. Bahakan Allah meliputi keadaan kamu. Lihat,
Artinya: Hai jemaah jin dan manusia, jika kamu sanggup menembus (melintasi) penjuru langit dan bumi, maka lintasilah, kamu tidak dapat menembusnya melainkan dengan kekuatan.

Berkaitan dengan budaya literasi di sosial media Azimah Soebagijo (2008: 130) didefinisikan sebagai kemapuan untuk mengakses, menginterprestasi, menganalisis, mengevaluasi dan menggunakan seluruh bentuk media. ${ }^{10}$ Selain itu, media literasi erat kaitannya dengan keterampilan berfikir kritis atau dengan kata lain keteramapilan untuk membantu sesorang untuk mengerti tetang makna dari sebuah pesan yang mereka terima dan mengetahui bagimana menggunakan informasi pesan tersebut.

\section{PROSES PENERIMAAN INFORMASI}

Proses penerimaan informasi dari sumber ataupun faktor-faktor yang berasal dari personal dan eksternal akan diberi makna yang berlainan oleh orang yang berbeda. Proses penerimaan dan pengolahan informasi pada diri manusia ini disebut dengan komunikasi interpersonal. ${ }^{11}$ Dalam proses penerimaan informasi, alat indera merupakan faktor yang menentukan. Hal ini karena stimulasi biasanya lebih dominan datang dari luar diri seseorang yang kemudian ditangkap melalui panca indera. ${ }^{12}$

Menangkap rangsangan (stimulus) melalui panca indera ini kemudian dikenal dengan istilah sensasi. Pada sistem rangsangan hewan mekanisme ini dipengaruhi oleh faktor kimiawi

Muhammad Nasib Ar-Rifa'I, Kemudahan dari Allah: Ringkasan Tafsir Ibnu Katsir, (Jakarta: Gema Insani Press 2000), hlm. 546.

10 Azimah Soebagijo, Pornografi Tapi dilarang Dicari, (Jakarta: Gema Insani. 2008), hlm. 130.

${ }^{11}$ Lucy Pujasari Supratman dan Adi Bayu Mahadian, Psikologi Komunikasi, (Yogyakarta: Deepublish. 2016), hlm. 44.

12 Selain lima panca indera yang dikenal, terdapat juga dua alat indera lain yang disebut 
(kemoresepsi), dimana terjadi interaksi antara bahan kimia dengan kemoreseptor yang kemudian membentuk potensi generator reseptor. Proses ini akan menghasilkan reaksi dari sel saraf sensoris dan sel saraf berikutnya sehingga menghasilkn apa yang disebut dengan respon. Respon ini terbetuk proses pengkodean dilanjutkan dengan penafsiran kode sebelum akhirnya menjadi tanggapan. Penjelasan tersebut sebagaimana dapat dilihat pada gambar berikut:

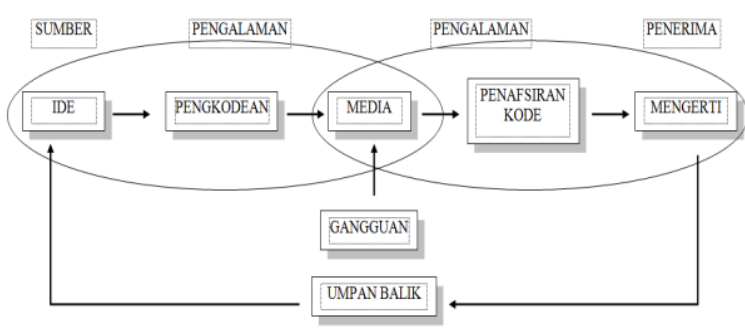

Adapun tingkatan tentang sejauh mana stimulus dan pengaruhnya terhadap pengalaman belajar, hal ini dapat dilihat pada kerucut pengalaman belajar sebagai berikut:

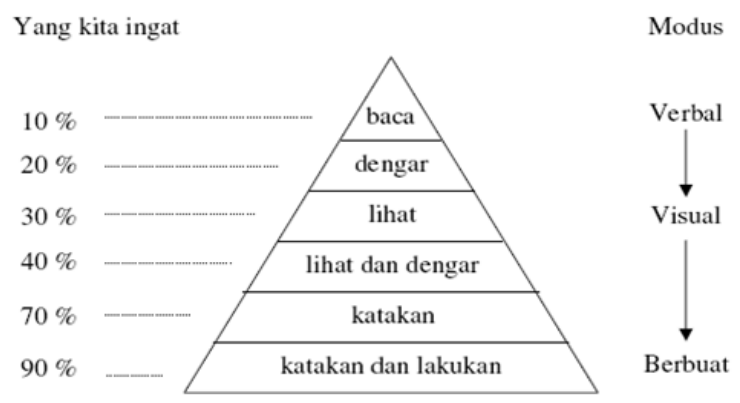

Berdasarkan kerucut pengalaman belajar di atas jika belajar hanya mengandalkan kemampuan membaca hal ini hanya berdampak 10 persen pada pengalaman belajar seseorang. jika dilanjutkan pada tingkat mendengar maka akan menghasilkan 20 persen pengalaman saja. Jika dilihat maka akan memperoleh 30 persen pengalaman. Jika dilihat dan didengar maka akan menghasilkan 40

dengan kinesetis dan vestibular. Kinesitas aalah adalah indera yang mengatur gerak dan posisi tubuh dan anggota badan lainnya dalam bertindak. persen pengalaman. Jika dikatakan akan menghasilkn 70 persen pengalaman dan jika dikatakan dan dilakukan akan memperoleh 90 persen pengalaman.

\section{RAGAM PEMANFAATAN SOSIAL MEDIA}

Pada masyarakat akademis sosial media khususnya facebook dan twitter tidak banyak memberikan kontribusi terhadap perkembangan budaya literasi yang bersifat ilmiah di Perguran Tinggi. Facebook dan twitter lebih diperuntukkan sebagai sarana komunikasi, silahturahmi, diskusi, sharing informasi dan menulis opini. Meskipun demikian, dari komunikasi-komunikasi yang ringan ini biasanya akan muncul ide dan gagasan yang menarik untuk kemudian dirangkai menjadi sebuah tulisan yang bersifat ilmiah.

Lahirnya ide dan gagasan menarik ini biasanya karena beberapa faktor. Pertama, komposisi pertemanan di sosial media biasanya berasal dari beragam latar belaang pendidikan, etnis, usia, jenis kelamin agama, profesi dan lain-lain. Dengan beragamnya latar belakang pertemanan tersebut, maka akan terungkap berbagai persoalan menarik dari sesuai dengan klusternya masing-masing. Kedua, dengan banyaknya pertemanan di sosial media akan diketahui secara pasti berbagai perkembangan informasi terkini seputar tren sosial, teknologi dan lain-lain secara online. Hal ini adalah modal bagi seseorang untuk dapat selalu update dalam menerima informasi yang berasal dari berbagai sumber. Ketiga, sosial media juga menjadi arena kritik dan saran bagi orang lain untuk dapat mengembangkan lagi kualitas pemikiran dan tulisannya. Pada titik ini pengguna sosial media yang berasal dari akademisi akan menguplod opininya dan kemudian dari opininya tersebut akan muncul beragam reaksi dari netizennya. Disitu

Sedangkan Vestibular, adalah indera yang berfunsi sebagai alat keseimbangan. 
penulis opini akan melihat kelemahan dan kelebihan dari opini yang telah ia buat.

Sebuah jejaring pertemanan di sosial media juga memiliki semacam seleksi alam, dimana orang yang tidak disukai dan memiliki cap negatif akan dijauhi, disisihkan, dihapus (delcon: delet contat) dari daftar teman ataupun member dalam sebuah grup. Cara lainnya adalah dengan tidak merespon perkataan ataupun segala aktivitasnya dalam status. Sosial media juga adalah lautan manusia yang memiliki hati nurani dan mampu membedakan mana baik dan mana buruk. Hukumnya sama saja dengan masyarakat nyata di keseharian yang memiliki norma-norma yang mengatur dan memberikan petunjuk mengenai perbuatan yang harus dilakukan dan perbuatan yang harus dihindari dalam kehidupan masyarakat. Mereka tidak terlalu toleran pada segala hal yang buruk atau dianggap bertentangan dengan normanorma masyarakat. Maka seorang manusia yang sejak awal punya misi hanya mengejar materi belaka siap-siap saja tercampakan dari ajang pergaulan media sosial (Merry Magdalena, 2010: 32). ${ }^{13}$

Yanti Herlanti (2014: 3) menyatakan bahwa sosial media mempunyai kelebihan dalam sifat komunikasi. Sifat komunikasi ini berbentuk tulisan dalam bentuk maya (online) dan menciptakan lingkungan belajar yang partisipatif. ${ }^{14}$ Sifat dan kelebihan sosial media menjadikan siskusi dapat dirancang durasinya dan luas jangkauannya.

Media literasi juga menjadi semacam jawaban atau solusi atas berbagai masalah seputar dampak media terhadap penggunanya. Hal ini karena menurut Azimah Soebagijo (2008: 131) tujuan media literasi adalah memberikan pemahaman kepada seseorang tentang manfaat dan kerugian dari media massa

${ }^{13}$ Merry Magdalena, Public Relations Ala Wima, (Jakarta: Gramedia. 2010), hlm. 32.

${ }^{14}$ Yanti Herlanti, Blogquest+: Pemanfaatan Media Sosial Pada Pembelajaran Sains Berbasis Isu Sosiosintifik Untuk Mengembangkan Keterampilan sehingga ia dapat bersikap kritis terhadap isi media yang buruk dan senang mngkonsumi media yang sehat, bahkan menjadi termotivasi untuk mengembangkan diri untuk memproduksi media yang sehat. ${ }^{15}$

Setiap orang hendaknya perlu untuk mengembangkan keahlian melek media. Terutama dalam menyikapi pesan-pesan dari media yang semakin canggih dalam hal mempengaruhi cara berpikir, merasa, bersikap dan berperilaku. Jika di Amerika Utara sejak tahun 1978 media literasi telah menjadi salah satu topik penting kurikulum pendidikan di sekolah-sekolah, maka di Indonesia media literasi seharusnya sudah diintegrasikan ke dalam kurikulum pelajaran di kelas sebagai salah satu keterampilan dasar berkomunikasi.

Menjadi melek media memerlukan keterampilan berpikir kritis yang menuntun sesorang agar dapat mengambil berbagai informasi terkait dengan informasi di media masa dan berguna bagi kehidupannya. Sehingga orang yang menguasai ilmu tentang melek media akan memahami proses komunikasi yang disajikan media. Mereka akan mampu mengubah dan merespon pesan dalam media menjadi lebih komprehensif, utuh dan sesuai dengan tuntutan norma yang berlaku di masyarakatnya.

Jumlah pengguna yang besar menjadikan sosial media dibidik oleh individu maupun suatu kelompok/golongan tertentu untuk mengiring opini publik demi mencapai tujuannya. Lemahnya pengawan dan tindakan hukum tersebut bukanlah tanpa alasan, sebab sosial media terbilang sulit untuk dikendalikan sementara tidak ada kewajiban bagi penggunanya untuk memiliki sertifikat atau izin khusus dari pihak berwajib seperti uji kelayakan tentang siapa yang boleh atau tidak boleh menjadi pengguna sosial media. Tidak menghernkan

Berargumentasi dan Literasi Sains, (Bandung: Sekolah Pasca Sarjana Universitas Pendidikan Indonesia. 2014), hlm. 3.

${ }^{15}$ Azimah Soebagijo. Op. Cit., hlm. 131. 
jika banyak postingan berita palsu atau hoax yang berasal dari akun bodong (palsu) yang kemudian menjadi viral dan bertebaran di dunia maya.

Hoax muncul di dalam masyarakat sebagai reaksi dan kurangnya referensi sebagai dampak lemahnaya budaya literasi. Akibatnya adalah terbangun suatu opini labil tanpa melalui proses cek dan ricek terhadap suatu persoalan yang menyebabkan kecenderung untuk menuju arah anarkis. Hal ini seperti pada kasus berita palsu kebakaran, ancaman bom, terjadinya tsunami bahkan yang terparah adalah isu dukun santet yang pernah bertebaran melalui Short Message Service (SMS) pada tahun 2008 dan berakhir pada kematian sejumlah orang tak bersalah. ${ }^{16}$

Persoalan lain mengenai munculnya hoax adalah munculnya segeombolan netizen pengguna media jejaring sosial yang terhipnotis dengan berita instan yang dianggap terupdate. Biasanya berita ini disajikan oleh sebuah group informasi semisal facebook maupun dari para sukarelawan yang senang berbagi informasi gratis. Di satu sisi pelaku mendapat kepuasan tersendiri berupa banyaknya like (acungan jempol), komentar dan beritanya kemudia di share. Disisi lain, penerima berita yang tidak selektif merasa diuntungkan karena menganggap dirinya lebih tahu berita terkini dan lebih banyak tahu dibandingkan dengan orang lain. Pada beberapa kasus tipe pengguna seperti ini memiliki banyak akun palsu untuk emperoleh informasi dari berbagai sumber dan senang melakukan bully di media sosial terhadap tokoh atau karakter yang tidak disukainya.

Berangkat dari berbagai paparan di atas seorang individu hendaknya bersikap tabayun atau teliti, dengan melakukan check dan recheck serta mengklarifikasi jika memperoleh informasi apalagi yang berkaitan dengan kepentingan umat. Hal ini

16 Agung Herutomo. 2010 Data Mining: Meraalkan Bisnis Perusahaan, (Jakarta: PT. Elex Media Komputindo. 2010), hlm. 70. sebagaimana diperintahkan Allah SWT dalam surah Al-Hujarat (42): 12, yang artinya:

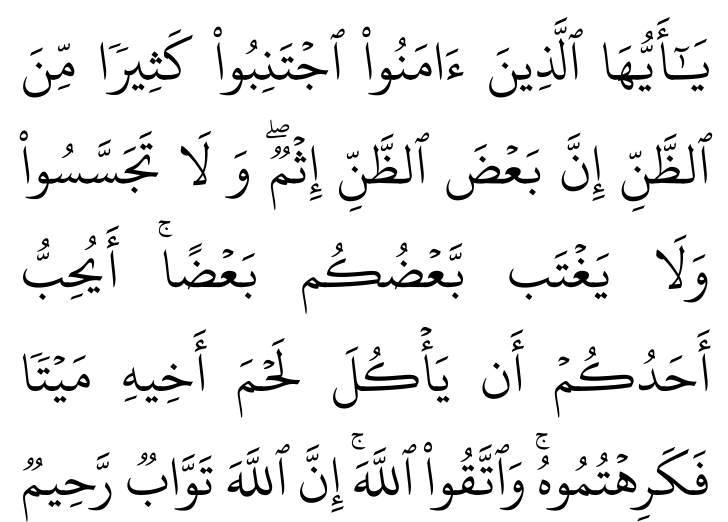

Artinya: Hai orang-orang yang beriman, jauhilah kebanyakan dari prasangka, sesungguhnya sebagian prasangka itu adalah dosa dan janganlah kamu mencari-cari kesalahan orang lain dan janganlah sebahagian kamu menggunjing sebaha-gian yang lain. Sukakah salah seorang di antara kamu memakan daging saudaranya yang sudah mati? Maka tentulah kamu merasa jijik kepadanya. Dan bertakwalah kepada Allah. Sesungguhnya Allah Maha Penerima tobat lagi Maha Penyayang.

Tidak hanya dengan cara sebagaimana telah disebutkan di atas. Ada beberapa trik juga yang dapat dilakukan untuk mengatasi atau menangkal berbagai konten negatif di sosial media, diantaranya:

1. Tidak mudah percaya dengan judul, artinya jangan mudah terprovokasi dengan judul sebelum membaca berita/ cerita dengan lengkap. Pembaca hendaknya lebih teliti dalam melihat isi berita dan mengkajinya lebih lanjut sebelum bersikap dan bertindak. Jikapun hanya memabaca judul usahakan tidak langsung bereaksi sebelum benar-benar di telaah lebih lanjut.

2. Perhatikan link berita atau URL dengan menyelidiki sumbernya. Berita bernada negatif adakalanya disebarkan pelaku melalui jejaring sosial media seperti 
facebook dan twitter dengan mencantumkan link atau URL. Namun sebagai pembaca yang baik hendaknya turut memperhatikan secara detil alamat dan format link yang digunakan. Hal ini karea bisa saja tulisan tersebut bukan dari link berita resmi yang dapat dipertanggungjawabkan keberannya

3. Amati tanda baca, diksi dan tata letak (formatan). Pada beberapa kasus di sosial media yang memberitakan konten negatif dan mengujar pada kebencian (hate speech) kadang ditulis tanpa melalui proses editing. Sehingga bisa saja ditemukan kesalahan pengetikan, tanda baca, atau kalimat yang tak lengkap. Inillah salah satu perbedaan antara berita sebenarnya dengan berita yang mengarah pada konten negatif.

4. Perhatikan foto. Foto yang digunakan pada berita yang berisi konten negatif berbentuk dari gambar editan atau telah mengalami proses prubahan dari yang sebenarnya. Perhatikan dengan seksama kualitas gambarnya dan juga tata letak gambar atau obyek didalamya. Jika ada yang buram /blur dan sejenisnya kemungkinan besar telah dilakukan rekayasa.

5. Periksa tanggal. Berita bernada negatif yang dibuat oleh penulisnya ada kalanya mengambil peristiwa lama atau di masa lalu yang sengaja dikait-kaitkan dalam rangka membentuk opini. Jika ini benar ditemukan maka ada kemungkinan ini hanya berita hoax yang mengiring opini publik.

6. Klarifikasi bukti. Bukti menjadi sumber penting dalam mengungkap kebenaran berita. Tanpa adanya bukti maka fakta dari suatu peristiwa tidak dapat dinyatakan benar adanya.

7. Bandingkan berita. Jika sudah terdapat berita yang dibaca hendaknya dibandingkan dengan sumber lain yang kredible. Artinya tidak hanya berdasarkan dari sumber tunggal melainkan juga dari sumber lain yang juga dapat dipertanggungjawabkan.

\section{PENUTUP}

Dalam suatu masyarakat post-modern yang telah maju dan berperadaban tinggi, terdapat kecenderungan konvergensi antara dunia akademik dan nilai-nilai normatif dengan dunia praktik yang cenderung opurtunies dan prgmatis. Lebih lanjut, dari berbagai penjelasan sebagaimana tertulis di atas, secanggih apapun teknologi yang dipakai, tidak akan efektif apabila sejak awal seseorang memang sudah tidak berlandaskan pada visi dan misi yang benar. Media sosial sekalipun yang dianggap canggih akan kehilangan kemampuannya selama manusianya tidak berpihak pada kebenaran. Akan tetapi beda ceritanya jika seseorang sejak awal yakin bahwa ia memihak pada kebenaran, maka media sosial menjadi alat efektif untuk menjalankan misinya.

Sebagai bagian dari civitas academica, seyogyanya setiap orang wajib membangun budaya inetelektual yang positif dalam rangka meningkatkan keberlang-sungan dan pembangunan masyarakat akademik pada umumnya. Sebab, dari rahim masyarakat akademik ini pula akan terlahir manusia-manusia yang produktif, kreatif dan inovatif serta berkarya bagi kemajuan nusa bangsa dan negaranya. Selain itu, sebagai masyarakat akademis, sikap kejujuran, kebenaran dan keber-manfaatan hendaknya dapat dipegang dalam menjalankan seluruh aktivitas akademik. 


\section{DAFTAR PUSTAKA}

A. Ranu Usman. 2009. Etnis Cina Perantau di Aceh. Jakarta: Yayasan Pustaka Obor Indonesia.

Agung Herutomo. 2010. Data Mining: Meraalkan Bisnis Perusahaan. Jakarta: PT. Elex Media Komputindo.

Azimah Soebagijo. 2008. Pornografi Tapi Dilarang Dicari. Jakarta: Gema Insani.

Buletin ASEAN: Media Publikasi Direktorat Jenderal Kerjasama ASEAN Kementerian Luar Negeri RI. Edisi 3 Nopember 2013.

Muhammad Nasib Ar-Rifa'i. 2000. Kemudahan dari Allah: Ringkasan Tafsir Ibnu Katsir. Jakarta: Gema Insani Press.

Elizabeth Tjahjadarmawan. 2017. Ngopi Dulu. Yogyakarta: Deepublish.

Lucy Pujasari Supratman dan Adi Bayu Mahadian. 2016. Psikologi Komunikasi. Yogyakarta: Deepublish.

Merry Magdalena. 2010. Public Relations Ala Wimar. Jakarta: Gramedia.

Nufransa Wira Sakti. 2014. Buku Pintar Pajak E-Commerce: Dari Mendaftar Sampai Bayar. Ciganjur: Visimedia.

Rhenald Kasali. 2008. Mutasi DNA Powerhouse. Jakarata: PT. Gramedia Pustaka Utama.

Ridwan Sanjaya, Christine Wibhowo, Arista Prastyo Adi. 2010. Parenting Untuk Pornografi di Internet. Jakarta: PT. Gramedia.

Riris K. Toha Sarumpaet. 2016. Krisis Budaya? Oasis Guru Besar Fakultas Ilmu Pengetahuan Budaya UI. Jakarta: Yayasan Pustaka Obor Indonesia.
Sarinah. 2016. Ilmu Sosial Budaya Dasar: Di Perguruan Tinggi. Yogyakarta: Deepublish.

Yanti Herlanti. 2014. Blogquest+: Pemanfaatan Media Sosial Pada Pembelajaran Sains Berbasis Isu Sosiosintifik Untuk Mengembangkan Keterampilan Berargumentasi dan Literasi Sains. Bandung: Sekolah Pasca Sarjana Universitas Pendidikan Indonesia. 